\title{
Integrin a $2 \beta 1$ inhibits MST1 kinase phosphorylation and activates Yes-associated protein oncogenic signaling in hepatocellular carcinoma
}

\author{
Kwong-Fai Wong ${ }^{1,2}$, Angela M. Liu ${ }^{1,2}$, Wanjin Hong ${ }^{3}$, Zhi Xü ${ }^{4}$, John M. Luk ${ }^{1,2,5,6}$ \\ ${ }^{1}$ Department of Pharmacology, National University Health System, Singapore \\ ${ }^{2}$ Department of Surgery, National University Health System, Singapore \\ ${ }^{3}$ Institute of Molecular and Cell Biology, Biopolis, Singapore \\ ${ }^{4}$ Department of Oncology, Nanjing First Hospital, Nanjing Medical University, Nanjing, China \\ ${ }^{5}$ Department of Pathology, University of Hong Kong, Queen Mary Hospital, Pokfulam, Hong Kong \\ ${ }^{6}$ Department of Translational and Clinical Medicine, Arbele Limited, Hong Kong Science Park, Shatin, Hong Kong \\ Correspondence to: John M. Luk, email: dr.johnluk@gmail.com \\ Zhi Xu, email: michelle.xuzhi@hotmail.com \\ Keywords: extracellular stimuli, hippo pathway, liver cancer, MST1, Yes-associated protein
}

Received: August 01, $2016 \quad$ Accepted: September 25, $2016 \quad$ Published: October 19, 2016

\section{ABSTRACT}

The Hippo pathway regulates the down-stream target Yes-associated protein (YAP) to maintain organ homeostasis, which is commonly inactivated in many types of cancers. However, how cell adhesion dysregulates the Hippo pathway activating YAP oncogene in hepatocellular carcinoma (HCC) remains unclear. Our findings demonstrate that $\alpha_{2} \beta 1$ integrin (but not other $\beta 1$ integrins) expressed in HCC cells, after binding to collagen extracellular matrix, could inhibit MST1 kinase phosphorylation and activate YAP pro-oncogenic activities. Knockdown of integrin a 2 gene (ITGA2) suppressed YAP targeted gene expression in vitro. $\mathbf{a} 2 \beta 1$ and collagen binding resulted in suppressing Hippo signaling of mammalian sterile 20-like kinase 1 (MST1) and Large tumor suppressor homolog 1 (LATS1) with concomitant activation of YAP-mediated connective tissue growth factor (CTGF) gene expression. In vitro kinase assay showed that MST1 is an immediate downstream target of integrin a2 with $\mathbf{S 1 1 8 0}$ residue as the critical phosphorylation site. Clinical correlational analysis using a gene expression dataset of 228 HCC tumors revealed that ITGA2 expression was significantly associated with tumor progression, and co-expression with YAP targeted genes (AXL receptor tyrosine kinase, CTGF, cyclin D1, glypican 3, insulin like growth factor 1 receptor, and SRY-box 4) correlated with survivals of HCC patients. In conclusion, a2 $\beta 1$ integrin activation through cellular adhesion impacts the Hippo pathway in solid tumors and modulates MST1-YAP signaling cascade. Targeting integrin a2 holds promises for treating YAP-positive HCC.

\section{INTRODUCTION}

Hepatocellular carcinoma (HCC) is a common cancer worldwide with over 700,000 new incidences per year [1,2], and the major risk factor is associated with chronic hepatitis B infection [3]. Surgery remains the primary curative treatment for HCC for whom approximately $20 \%$ patients diagnosed in early stages, whereas the postoperative long-term survivals are still poor because of a high recurrence rate [4].
To dissect the genetic casualty of HCC initiation and progression, and to identify potential therapeutic target for HCC treatment, we employed a mosaic HCC mouse model and identified Yes-associated protein (YAP) as a bona-fide oncogene in liver cancer $[5,6]$. YAP and its paralogue TAZ (transcriptional co-activator with PDZ-binding motif) are transcriptional co-activators regulated by the evolutionarily conserved Hippo pathway. The pathway components include two kinases named mammalian sterile 
20-like kinase 1/2 (MST1/2), and Large tumor suppressor homolog $1 / 2$ (LATS1/2).

Unlike that binding to extracellular matrix, cell-cell interaction activates MST1/2 thereby phosphorylating LATS1/2 using SAV1 as a cofactor. Activated LATS1/2 (in complex with Mob1) subsequently phosphorylates YAP at S127 and TAZ at S89, resulting in their cytoplasmic sequestration by 14-3-3 proteins [7-9] and proteosomal degradation of YAP/TAZ [10, 11]. During cell proliferation or organ regeneration (for instance, after partial hepatectomy) the Hippo pathway is inactivated, unleashing YAP and/or TAZ proteins for translocation into the nucleus, where YAP/TAZ protein interacts with transcriptional factors such as TEADs to "switch on" a wide range of genes involved in cell proliferation, dedifferentiation, and survival [12]. In cancer cells the Hippo pathway is also inactivated, allowing nuclear YAP/TAZ to modulate genes for metastasis [13-16]. Our previous study on HCC clinical samples revealed aberrant nuclear YAP expression associated with the poor survival outcomes [17]. Recent study showed a cyclic-YAP peptide that disrupts YAP/TEAD interaction could inhibit HCC cell growth and survival [18].

YAP/TAZ are reported to regulate cell growth by sensing the cells toward the mechanical signals from extracellular matrix [19-22]. They are activated when cells are grown on a stiff matrix while inactivated when cells are grown on a soft matrix [23, 24]. Integrins are adhesion receptors in cell-matrix adhesion and $\alpha 2 \beta 1$ integrin was shown to induce MMP-7 expression through activating YAP independent of Hippo pathway [25]. $\alpha 2 \beta 1$ integrin of the $\beta 1$-integrin family is an extracellular matrix receptor for collagen and laminin [26]. In addition to its physiologic function, $\alpha 2 \beta 1$ integrin contributes to the tumor-stromal interaction that is important to cancer cell survival and metastasis [27-29]. Herein, the present study reports $\alpha 2 \beta 1$ integrin as a potential upstream negative regulator of the Hippo pathway in HCC, which upon activation through binding to collagen, directly inhibits MST1 kinase and activates the YAP-driven transcriptional activities.

\section{RESULTS}

\section{Integrin $\alpha 2$ is important for the expression of YAP targeted genes}

$\beta 1$-integrin family functions as collagen receptors and consists of 4 members: $\alpha 1 \beta 1, \alpha 2 \beta 1, \alpha 10 \beta 1$ and $\alpha 11 \beta 1$. To determine which member is involved in regulating the Hippo pathway in HCC, we knocked down each individual subunit gene, and studied the changes in gene expression mediated by YAP activation (using the previously reported gene set including $A X L, C T G F, C C N D 1$, and GPC3) in HCC cells $[30,31]$. Prior to the study the siRNAs were confirmed able to suppress respective integrin subunit expression by $>50 \%$ with no considerable off-target effects (Supplementary Figure S1). Results of experiment showed that knockdown of integrin a2 (ITGA2), but not other $\alpha$ subunits or $\beta 1$ subunit, yielded significant suppression of the YAP targeted gene expression of PLC/ PRF/5 (PLC) cells (Figure 1A). Similar knockdown effects could also be seen in Hep3B cells (Supplementary Figure S2).

We next investigated whether integrin $\alpha 2$ would sustain the expression of YAP targeted genes by modulating the Hippo core kinases MST1 and LATS1 [32]. As shown in Figure. 1B, knockdown of ITGA2 led to substantial increases in p-T183-MST1, p-S909-LATS1, and p-S127-YAP levels, indicating an activated Hippo pathway with an inhibited YAP. By contrast, knockdown of integrin $\beta 1(I T G B 1)$ or other pairing alpha subunits did not result in marked increase of the p-S127 YAP level. These findings suggest that integrin $\alpha 2$ plays a crucial and selective role in activating YAP by modulating the Hippo core kinases.

\section{Extracellular matrix (ECM) adhesion by $\alpha 2 \beta 1$ integrin inhibits the Hippo pathway}

ECM plays important roles in regulating cell physiology such as cell division and migration [33]. Recently YAP was suggested as a transcriptional mediator (or mechano-sensor) for cellular responses toward ECM stiffness via a Hippo pathway-independent mechanism [23]. It is therefore of interest to examine whether binding of $\alpha 2 \beta 1$ integrin to ECM collagen would modulate the Hippo pathway in HCC cells. Unlike other HCC cell lines that were tested and found constitutively active, $\alpha 2 \beta 1$ integrin of Huh7 cells is present in the resting state that is responsive to collagen-dependent activation under normal physiologic conditions $[34,35]$. As shown in Figure 2A (comparing lane 2 with lane 1), adhesion of Huh7 cells on collagen IV caused substantial decreases in the stimulatory phosphorylation at p-T183-MST1 and p-S909-LATS1, but increased the inhibitory phosphorylation at p-T387-MST1. Concomitant with these events, decrease of p-S127YAP and up-regulation of the YAP targeted gene $C T G F$ (right panel) were observed, implicating functional activation of YAP oncogene. Treatment of Huh7 cells with a functional blocker BHA2.1 antibody, which was shown to abolish the adhesive property of $\alpha 2 \beta 1$ integrin [36], could significantly suppress the collagen-induced $C T G F$ expression that was accompanied by increases in p-T183-MST1 and p-S909-LATS1 (reactivation of MST and LATS) (Figure 2A, lane 4). BHA2.1 was generated through immunization of $\mathrm{BALB} / \mathrm{c}$ mice with human fibrosarcoma HT1080 cells, and was shown able to bind $\alpha 2 \beta 1$ integrin transfectant cells in flow cytometry at 0.2 $\mu \mathrm{g} / \mathrm{mL}[37]$. 

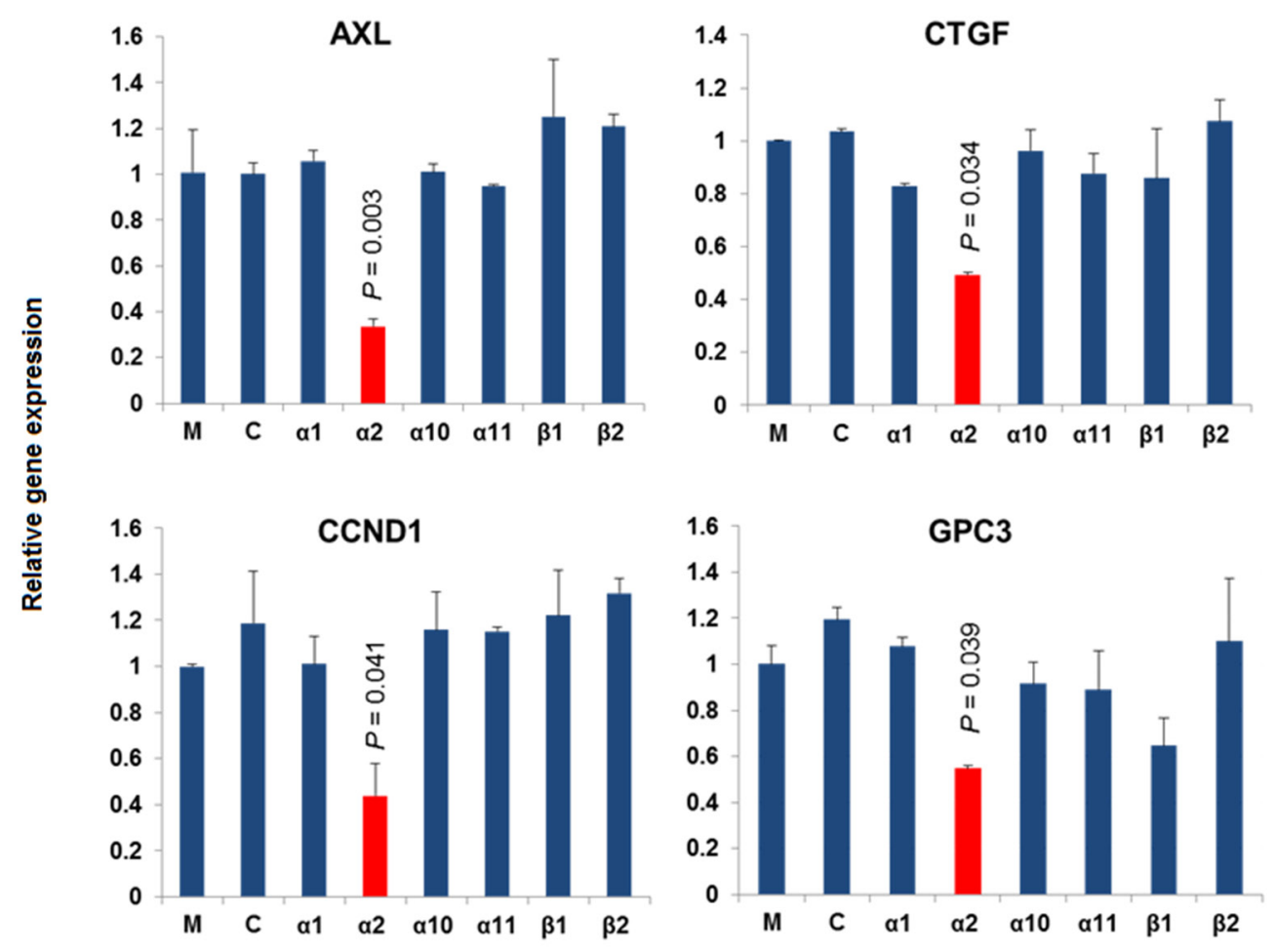

B siRNA Knockdown:

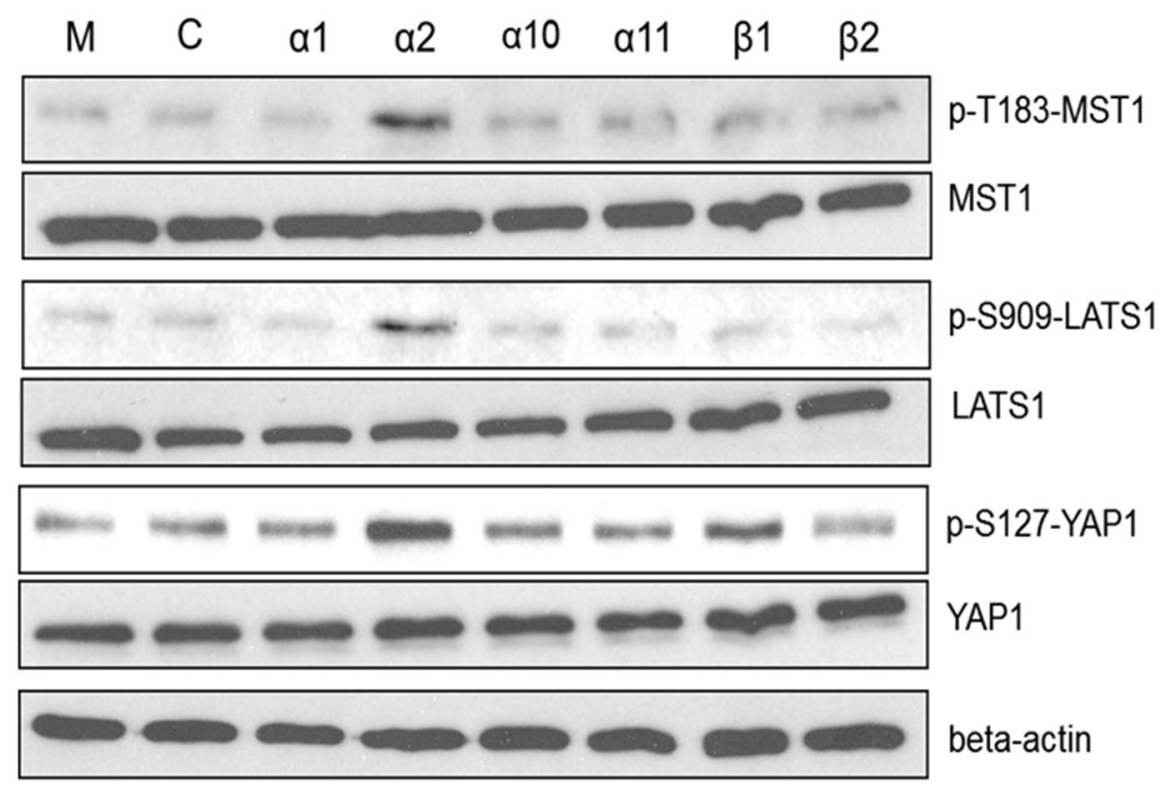

Figure 1. Integrin $\alpha 2$ is important for the expression of YAP targeted genes. A. Knockdown of ITGA2 in PLC cells suppressed significantly the expression of four YAP targeted genes ( $A X L, C C N D 1, C T G F$, and $G P C 3)$ comparing with the mock-treated groups. B. Knockdown of ITGA2 caused substantial increases in the phosphorylation at T183, S909, and S127 of MST1, LATS1, and YAP, respectively comparing with the groups treated with transfection reagent alone $(M)$ and scrambled siRNA $(C)$. All data shown are the representative of three independent experiments. 
In parallel, we demonstrated that knockdown of $I T G A 2$ and $I T G B 1$ could reverse the inhibitory effect of collagen IV on the Hippo pathway (Figure 2B). By contrast, the Hippo pathway of MIHA, a noncancerous hepatocyte cell line, was not responsive to the collagen IV treatment (Supplementary Figure S3). Taken together, adhesion of $\alpha 2 \beta 1$ integrin to collagen IV was shown to inhibit the function of MST1 and LATS1, and thus activates the YAP transcriptional activity in HCC.

\section{A}
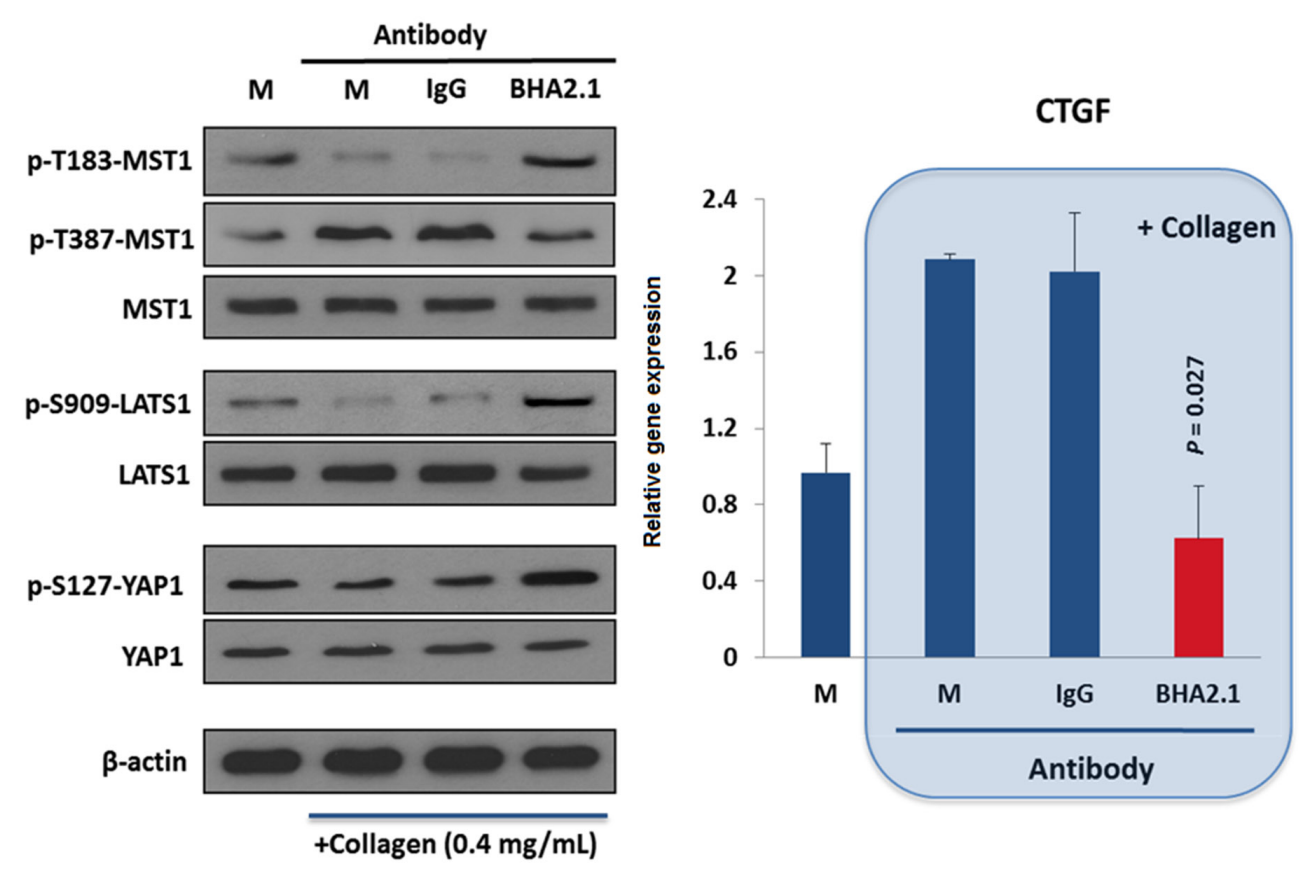

B
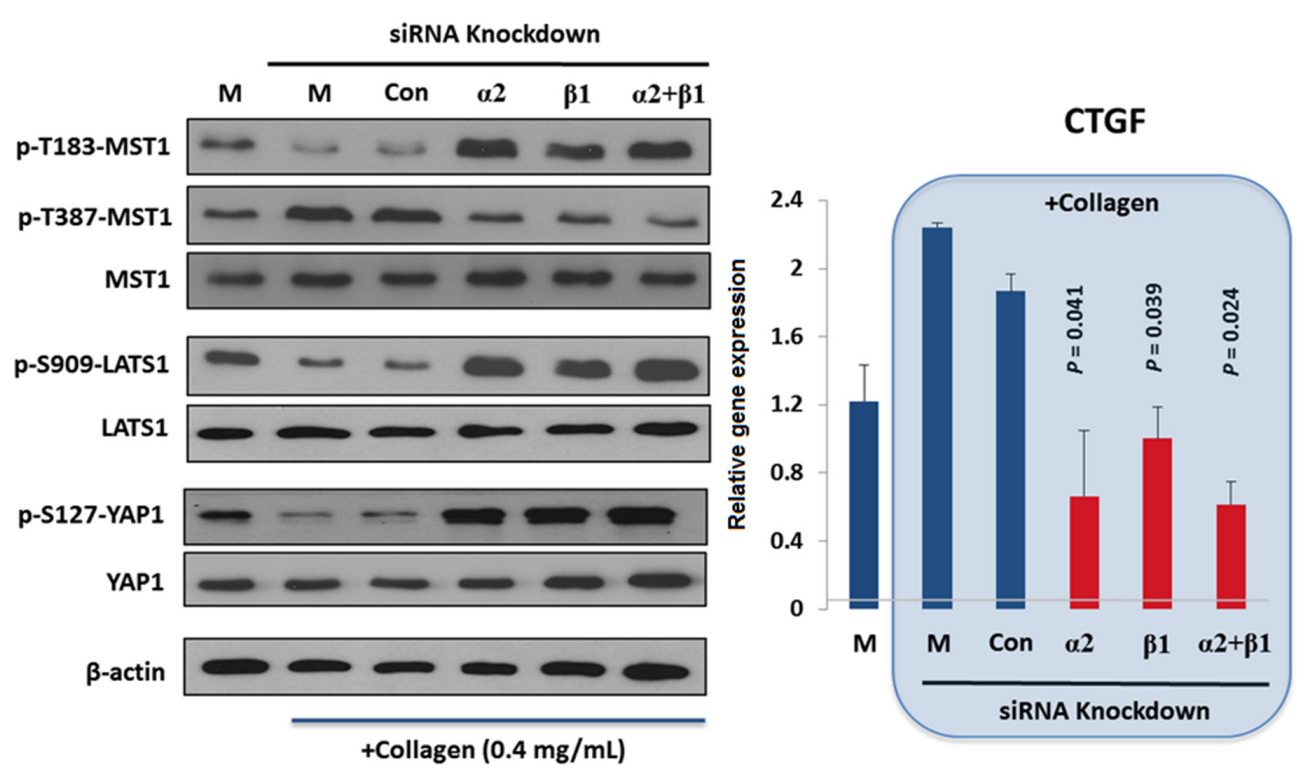

Figure 2. Extracellular matrix adhesion by $\alpha 2 \beta 1$ integrin adhesion inhibits the Hippo pathway. A. Adhesion of Huh7 cells to collagen IV reduced the stimulatory p-T183-MST1 and p-S909-LATS1 but increased the inhibitory p-T387-MST1, leading to a decrease in p-S127-YAP and in turn YAP-mediated CTGF expressions (right panel). Treatment of the cells with an integrin functionblocking antibody $(B H A 2.1)$, but not PBS $(M)$ and control $\operatorname{IgG}(\operatorname{Ig} G)$ antagonized the effect of collagen binding on Hippo pathway. B. Knockdown of ITGA2 $(\alpha 2)$ and ITGB1 ( $\beta 1)$ by siRNAs reversed the effect of collagen binding on Hippo pathway components, causing a significant reduction on CTGF expression comparing to the mock-treated group. All data shown are the representative of three independent experiments. 


\section{MST1 is an immediate downstream target of integrin $\alpha 2$}

In vitro kinase assay showed that knockdown of ITGA2 resulted in marked increases in the kinase activity of MST1 in Hep3B and PLC cells (Figure 3A).
Furthermore, $\alpha 2 \beta 1$ integrin was selectively co-precipitated with MST1 and p-T387-MST1 (inactive form) but not LATS1 and YAP (Figure 3B). To map the MST1-binding site(s) on $\alpha 2 \beta 1$ integrin, the cytoplasmic tails of each integrin subunit were expressed in $293 \mathrm{~T}$ cells as chimeric FLAG-tagged proteins for co-immunoprecipitation
A

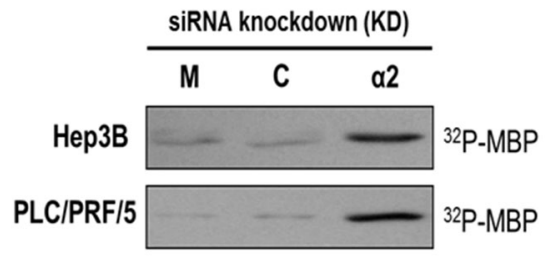

B

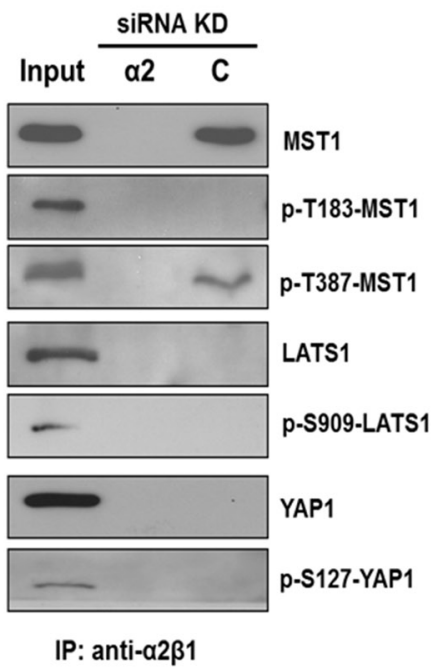

C
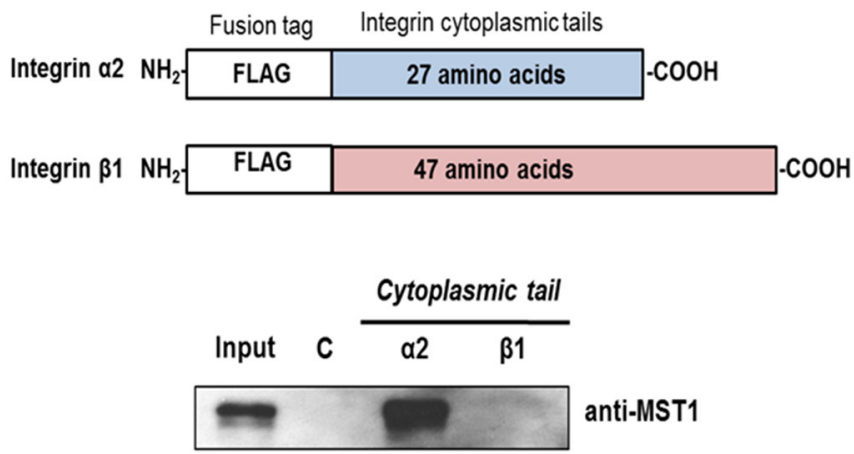

IP: anti-FLAG
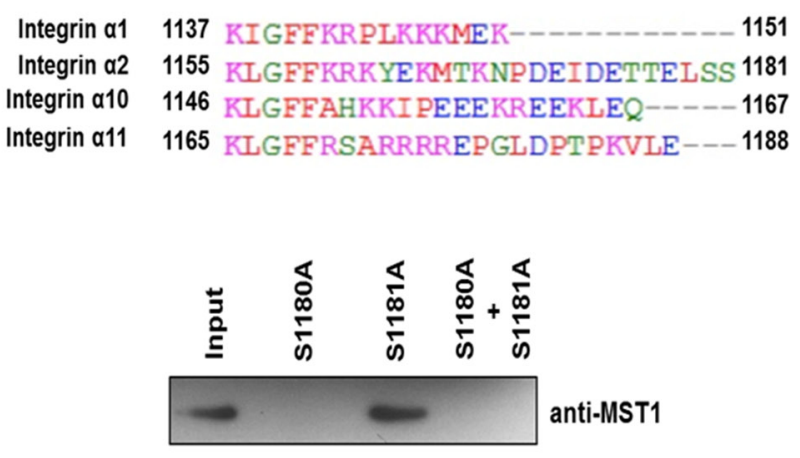

IP: anti-FLAG

Figure 3. MST1 is an immediate downstream target of integrin $\boldsymbol{\alpha 2}$. A. Endogenous MST1 was immunoprecipitated from Hep3B and PLC cells treated with control siRNA (C) or siRNA targeting ITGA2 $(\alpha 2)$ and subjected to in vitro kinase assay using myelin basic protein (MBP) as a substrate. Incorporation of radioactive ${ }^{32} \mathrm{P}$ into MBP was higher in the siRNA-ITGA2 treated group comparing to mock and control siRNA-treated group. B. In scrambled control siRNA-treated Hep3B cells $(C) \alpha 2 \beta 1$ integrin was coprecipitated with MST1 and p-T387-MST1 but not p-T183-MST1. No co-precipitation was observed with YAP and LATS1 proteins. Cell lysate obtained from siRNA-ITGA2-treated Hep3B cells $(\alpha 2)$ was also included as a negative control. C. The cytoplasmic tails of integrin $\alpha 2$ and $\beta 1$ were cloned, and individually over-expressed in 293T cells as FLAG-tagged proteins (top). Endogenous MST1 could be pulled down with the cytoplasmic tail of integrin $\alpha 2$ but not $\beta 1$ by the anti-FLAG affinity resin (bottom). D. Multiple sequence alignment showed integrin $\alpha 2$ differs from $\alpha 1, \alpha 10$, and $\alpha 11$ at its carboxyl end with two additional serine residues S1180 and S1181 (top). Integrin $\alpha 2$ cytoplasmic tail mutants with single mutation (i.e. S1180A or S1181A) and double mutations (i.e. $\mathrm{S} 1180 \mathrm{~A}+\mathrm{S} 1101 \mathrm{~A})$ were over-expressed in $293 \mathrm{~T}$ cells as FLAG-tagged proteins. Endogenous MST1 was not pulled down with the FLAG-tagged protein with S1180A mutation by the anti-FLAG affinity resin (bottom). All data shown are the representative set of two independent experiments. 
(Figure 3C, top). MST1 was precipitated with the cytoplasmic tail of integrin $\alpha 2$ but not the $\beta 1$ subunit by anti-FLAG tag affinity resin (Figure 3C, bottom). Homologous protein sequence alignment revealed that the cytoplasmic tail of integrin $\alpha 2$ differs from other integrin counterparts $\alpha 1, \alpha 10$, and $\alpha 11$ at the $\underline{\mathrm{S} 1180}$ and $\underline{\mathrm{S} 1181}$ residues (Figure 3D, top). To examine whether the serine residues would be essential to the interaction between integrin $\alpha 2$ and MST1, we showed that substitution of $\underline{\mathrm{S} 1180}$ with alanine prevented the co-precipitation of FLAG-tagged protein with MST1 (Figure 3D, bottom). These findings indicated MST1 is an immediate downstream target of $\alpha 2 \beta 1$ integrin, with MST1 binding to the cytoplasmic tail of integrin $\alpha 2$.

\section{FAK mediates $\alpha 2 \beta 1$ integrin inhibitory action on the Hippo pathway}

Focal adhesion kinase (FAK) plays important roles on integrin-ECM mediated adhesion signaling events [38]. We demonstrated herein that treatment of Hep3B cells with BHA2.1 blocker mAb abolished the stimulatory phosphorylation at Y397 of FAK and S473 of AKT (Figure 4A). To investigate whether FAK would mediate the integrin $\alpha 2$-MST1 signaling axis in response to collagen adhesion, we showed that treatment of Huh7 with FAK inhibitor Y15 could suppress the collageninduced FAK and AKT phosphorylation (Figure 4B). Along this line, we further showed that Y15 treatment could up-regulate the levels of p-T183-MST1, p-S909LATS, and p-S127-YAP (Figure 4C), suggesting FAK inhibition blocked integrin $\alpha 2$-mediated inhibition of the Hippo pathway.

\section{An integrin $\alpha 2$-activated YAP oncogenic signature predicts prognostic outcomes in $\mathrm{HCC}$ patients}

Our analysis on cDNA microarray data derived from 228 patients with HBV-related HCC demonstrated a stepwise increase in ITGA2 expression from nonneoplastic lesions (i.e. chronic hepatitis and cirrhosis) to early $\mathrm{HCC}$ and from early to late HCC (Figure 5A). Furthermore, as revealed by hierarchical clustering $I T G A 2$ co-expressed with YAP targeted genes (including $A X L, C C N D 1, C T G F, G P C 3, I G F 1 R, S O X 4)$ in $\mathrm{HCC}$ samples (Figure 5B). The co-expression could also be seen in a separate cohort of 24 HCC patients by RTqPCR (Supplementary Figure S4). To test the clinical significance of the co-expression, we generated a logistic regression model combining ITGA2 and YAP targeted genes, and determined the risk of co-expression of each patient. Kaplan-Meier analysis suggested the correlation of high risk score (i.e. $\geq$ median) with shorter overall $(P=0.027)$ and relapse-free $(P=0.030)$ survivals after hepatic surgery (Figure $5 \mathrm{C}$ ). The risk score was associated with different clinicopathological parameters as well (Table 1).

\section{DISCUSSION}

Cell-extracellular matrix interaction shows substantial impacts on cell fate because it is one of the major mechanical cues to regulate organ development and homeostasis [39, 40], and on the other hand, its pathological perturbations contribute to malignant progression by inducing cytoskeleton remodeling [41]. YAP and TAZ, the transcriptional co-activators regulated by the Hippo pathway, have been identified as effectors in response to ECM elasticity and cell shape, of which the mechanism involves the control of both co-activators by F-actin and stress fiber [20, 21, 42]. Mechanosensitive phenotypes can also be regulated by integrins and their association with YAP/TAZ. For example, the integrin-linked kinase (ILK) induced YAP/ TAZ nuclear localization through suppression of the Hippo pathway via phospho-inhibition of MYPT1-PP1 and inactivation of Merlin [43]. Stiff substrates enhanced colorectal cancer cell viability by upregulating MMP-7 expression through a positive feedback loop containing YAP, EGFR, integrin- $\alpha 2 \beta 1$ and MRLC, independent of Hippo pathway [25]. $\alpha 2 \beta 1$ integrin can directly interact with CDH17 through its RGD motif [44], which causes $\beta 1$ integrin activation and signaling to induce focal adhesion kinase and Ras activation, leading to colorectal cancer cells proliferation and liver metastasis [28]. Despite these important findings, the cell-surface components upstream the Hippo pathway and that sense the pathway to extracellular stimuli, especially in the context of pathogenesis like carcinogenesis, have remained to be elucidated. To address this unresolved question, the present work demonstrates that the binding of $\alpha 2 \beta 1$ integrin to collagen IV, which is the ECM that is highly accumulated in tumor interstitium [45, 46], inhibits the Hippo core kinases MST1 and LATS1, liberating YAP for its transactivation of gene expression in the nucleus (Figure 6). Our transcriptome analysis on HCC patients shows a stepwise increase in ITGA2 expression along the hepatocellular carcinogenic process, and patients co-expressing ITGA2 and YAP-targeted genes including $A X L, C C N D 1, C T G F, G P C 3, I G F 1 R$, $S O X 4$, were found to show more dismal prognosis after hepatic surgery. Thus, it is believed that HCC cells adherent to ECM collagen in tumor microenvironment capitalize $\alpha 2 \beta 1$ integrin to modulate the Hippo tumor suppressor functions thereby overcoming the general physiology of contact-contact inhibition.

Loss of MST1 activity results in tumor nodules formation in mouse livers [47], however the inactivation of MST1 in human HCC remains to be fully elucidated, although few regulators of MST1 have been proposed [48-51]. Here we show for the first time that in HCC cells 


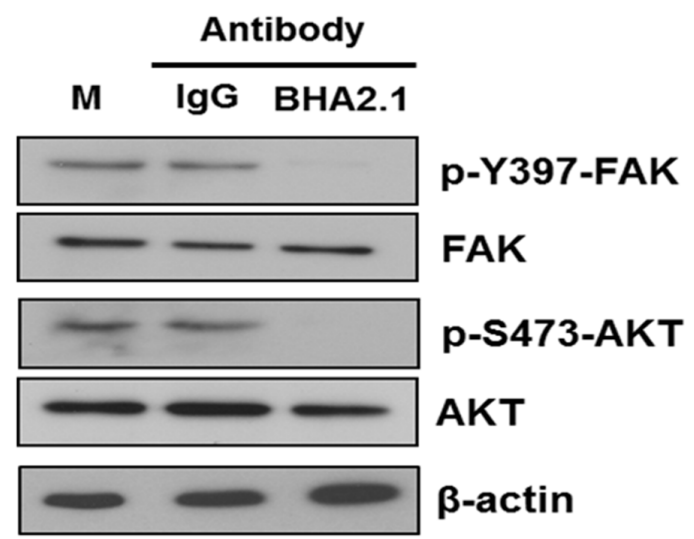

B

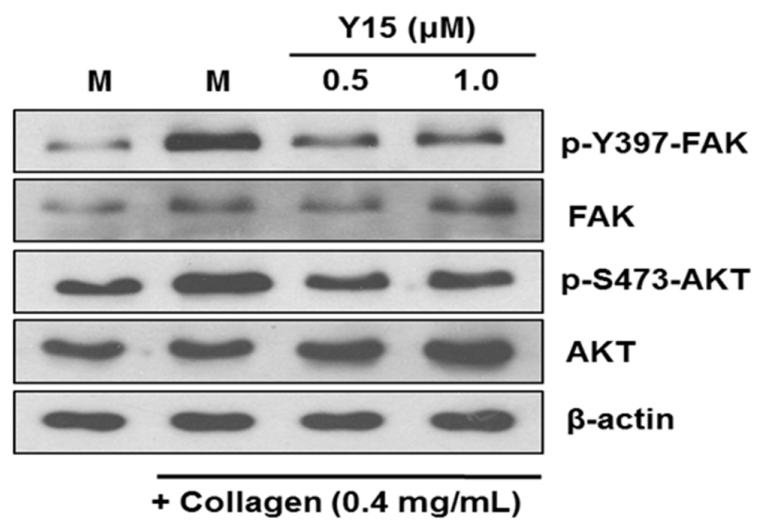

C

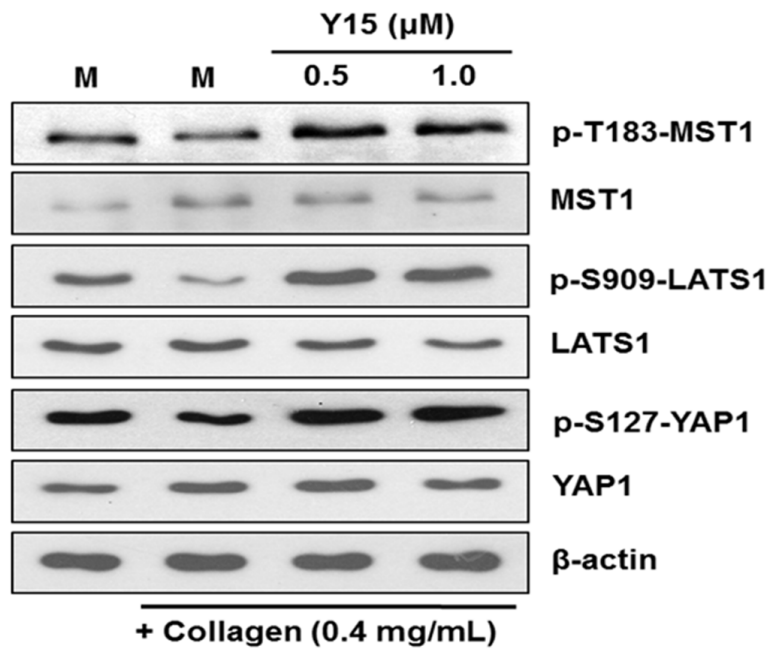

Figure 4. FAK mediates the action of integrin $\alpha 2$ on the Hippo pathway. A. Hep3B cells were treated with sterile PBS alone $(M)$, isotype-control $\operatorname{IgG}(\operatorname{IgG})$, and integrin function blocking antibody BHA2.1 (BHA2.1). Blocking the function of $\alpha 2 \beta 1$ integrin was demonstrated to decrease the stimulatory phosphorylation at Tyr397 and S417 of FAK and AKT, respectively. B. The effect of Y15 on FAK and AKT was studied in Huh7 cells cultured on immobilized collagen. Western blotting showed that collagen induced stimulatory phosphorylation of FAK and AKT at Y397 and S473, respectively. Treatment of Huh7 cells with 0.5 and $1.0 \mu \mathrm{M}$ Y15 decreased FAK and AKT phosphorylation to the levels comparable to those of the un-inactivated FAK and AKT. C. FAK inhibition was shown to abrogate the collagen regulation of the Hippo pathway. Comparing to the mock control, Huh7 cultured on immobilized collagen showed lower levels of p-T183-MST1, p-S909-LATS1, and p-S127-YAP1 of Huh7. Oppositely, treatment of Huh7 cells with 0.5 and $1.0 \mu \mathrm{M}$ Y15 could up-regulate the phosphorylation of MST1, LATS1 and YAP1. The effects were comparable to BHA2.1 blocker and integrin $\alpha 2$ siRNA treatment. All data shown are representative western blotting of two independent experiments. 
A

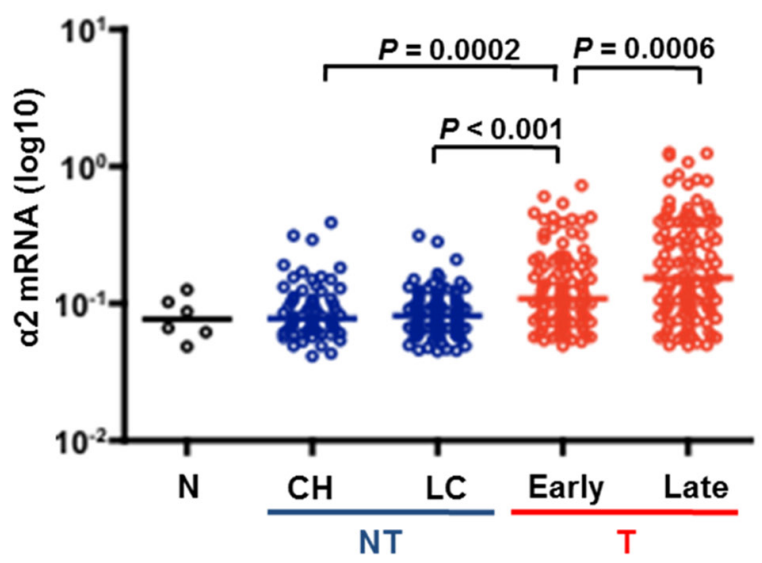

B

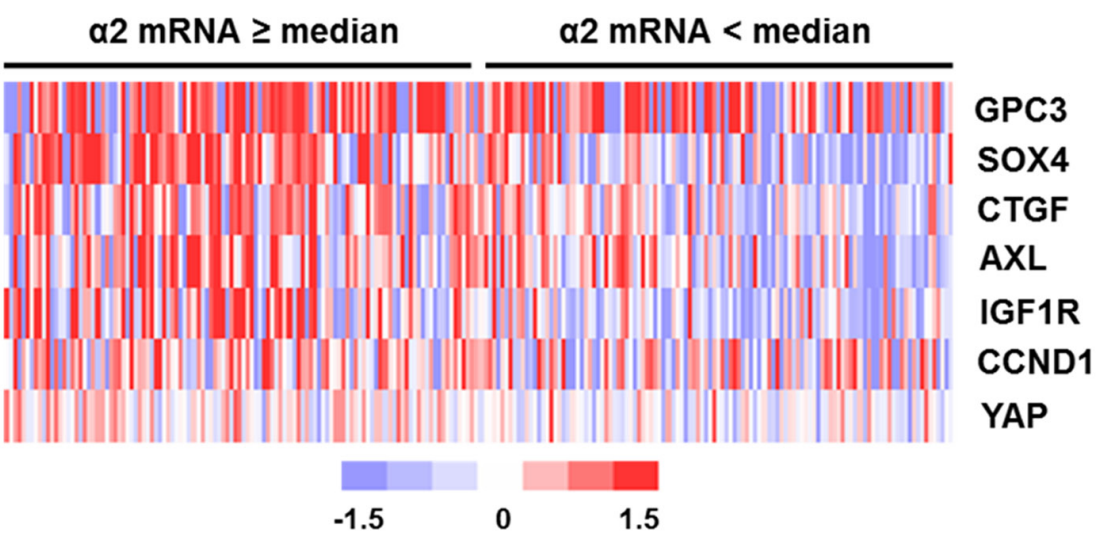

C
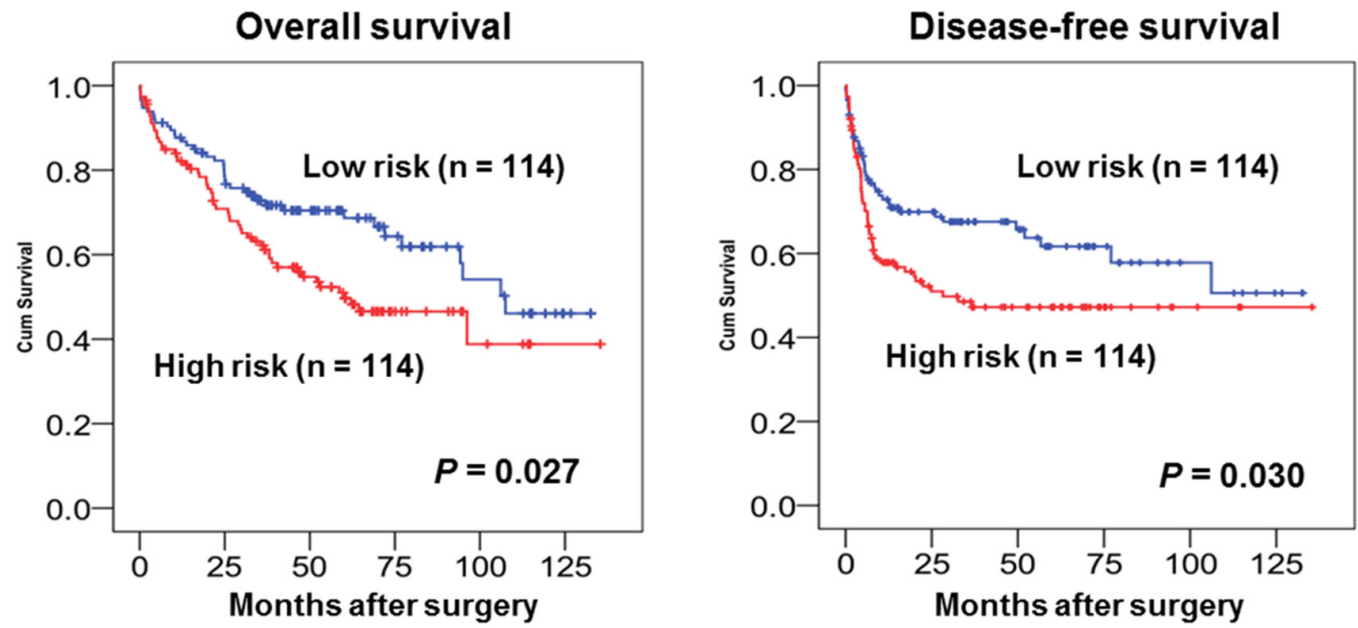

Figure 5. An integrin $\alpha 2$-activated YAP oncogenic signature predicts prognostic outcomes in HCC patients. A. Analysis of transcriptome data of $228 \mathrm{HCC}$ patients showed ITGA2 expression was elevated in HCC tumors comparing to non-neoplastic lesions like chronic hepatitis $(\mathrm{CH})$ and liver cirrhosis (LC). ITGA2 expression in late-stage tumor was also higher than in the early staged. B. Expression of a set of YAP-targeted genes ( $A X L, C C N D 1, C T G F, G P C 3, I G F 1 R$, and $S O X 4)$ was found higher in patients over-expressing integrin $\alpha 2$ (i.e. mRNA $\geq$ medium), comparing to patients with integrin $\alpha 2$ expression $<$ medium. Red, over-expression; blue, under-expression; white, no changes. C. Kaplan-Meier analysis illustrated the significant difference in overall $(P=0.027)$ and disease-free $(P=0.03)$ survivals between patients with high ( $\geq$ medium) and low ( $<$ medium) co-expression of ITGA2 and YAP-targeted gene set. 
Table 1: Clinical pathological correlation analysis of YAP-activated gene set with prognostic outcomes in HCC patients $(\mathbf{n}=\mathbf{2 2 8})$

\begin{tabular}{|c|c|c|c|c|}
\hline \multirow[t]{2}{*}{ Variables } & \multirow[t]{2}{*}{ Frequency (\%) } & \multicolumn{3}{|c|}{ Risk score } \\
\hline & & $<$ Median & $\geq$ Median & $P$ values \\
\hline \multicolumn{5}{|l|}{ Sex } \\
\hline Male & $179(78.5)$ & 97 & 82 & 0.016 \\
\hline Female & $49(21.5)$ & 17 & 32 & \\
\hline \multicolumn{5}{|l|}{ Age, years } \\
\hline$<55$ & $105(46.1)$ & 38 & 67 & $<0.001$ \\
\hline$\geq 55$ & $123(53.9)$ & 76 & 47 & \\
\hline \multicolumn{5}{|l|}{ Alcohol $(n=217)$} \\
\hline No & $133(61.3)$ & 66 & 67 & 0.907 \\
\hline Moderate/Heavy & $84(38.7)$ & 41 & 43 & \\
\hline \multicolumn{5}{|c|}{ Alpha fetoprotein, $\mathrm{ng} / \mathrm{mL}$} \\
\hline$<100$ & $116(50.9)$ & 82 & 34 & $<0.001$ \\
\hline$\geq 100$ & $112(49.1)$ & 32 & 80 & \\
\hline \multicolumn{5}{|l|}{ HBsAg } \\
\hline Negative & $31(13.6)$ & 17 & 14 & 0.562 \\
\hline Positive & $197(86.4)$ & 97 & 199 & \\
\hline \multicolumn{5}{|l|}{ Tumor size, $\mathrm{cm}$} \\
\hline$<5$ & $77(33.8)$ & 37 & 40 & 0.674 \\
\hline$\geq 5$ & $151(66.2)$ & 77 & 74 & \\
\hline \multicolumn{5}{|l|}{ TNM stage } \\
\hline Early (I, II) & $103(45.2)$ & 60 & 43 & 0.029 \\
\hline Late (III, IV) & $125(54.8)$ & 53 & 72 & \\
\hline \multicolumn{5}{|l|}{$\begin{array}{l}\text { Histological } \\
\text { differentiation }(n=191)\end{array}$} \\
\hline Well & $37(19.4)$ & 26 & 11 & 0.022 \\
\hline Moderate/Poor & $154(80.6)$ & 76 & 78 & \\
\hline \multicolumn{5}{|l|}{$\begin{array}{l}\text { Venous infiltration } \\
(n=227)\end{array}$} \\
\hline Absent & $114(50.2)$ & 68 & 46 & 0.007 \\
\hline Present & $113(49.8)$ & 45 & 68 & \\
\hline \multicolumn{5}{|l|}{ Tumor recurrence } \\
\hline Absent & $108(47.4)$ & 62 & 46 & 0.034 \\
\hline Present & $120(52.6)$ & 52 & 68 & \\
\hline
\end{tabular}


MST1 is a direct downstream target of $\alpha 2 \beta 1$ integrin. MST1 kinase activity is inhibited upon the binding of integrin receptor to ECM collagen. Our work suggests the inhibition of MST1 by $\alpha 2 \beta 1$ integrin depends on the physical interaction between the cytoplasmic tail of integrin $\alpha 2$ and MST1 kinase. Since integrin $\alpha 2$ selectively interacts with the inactivated p-T387-MST1, it is possible that the binding of integrin $\alpha 2$ to MST1 would prevent the dephosphorylation of p-T387 of MST1 by phosphatase, which is required for the full activation of MST1 [50]. The integrin $\beta 1$-linked FAK/ AKT may also be involved in the MST1 inhibition by $\alpha 2 \beta 1$ integrin because the effect of collagen on MST1 and LATS1 phosphorylation can be reversed by FAK inhibitor treatment.
Cytoplasmic tails of integrin $\alpha$ subunits are essential in determining the integrin-mediated downstream signaling [52-54]. Our present study identifies S1180 resident at the $\alpha 2$ cytoplasmic tail having a critical role for the binding of integrin $\alpha 2$ to MST1. As shown by sequence alignment the residue is exclusively present in integrin $\alpha 2$, but absent at the respective positions at integrin $\alpha 1, \alpha 10$, and $\alpha 11$ of other collagen receptor integrins. This finding may explain why only knockdown of integrin $\alpha 2$ can reduce YAP-mediated gene expression, and strengthens the unique functional role of $\alpha 2 \beta 1$ integrin in HCC. Therapeutic options for patients with advanced HCC are still limited. It is of great interest to investigate whether interrupting the interaction between integrin $\alpha 2$ and MST1 would show therapeutic potential for treatment of YAP-positive HCC.

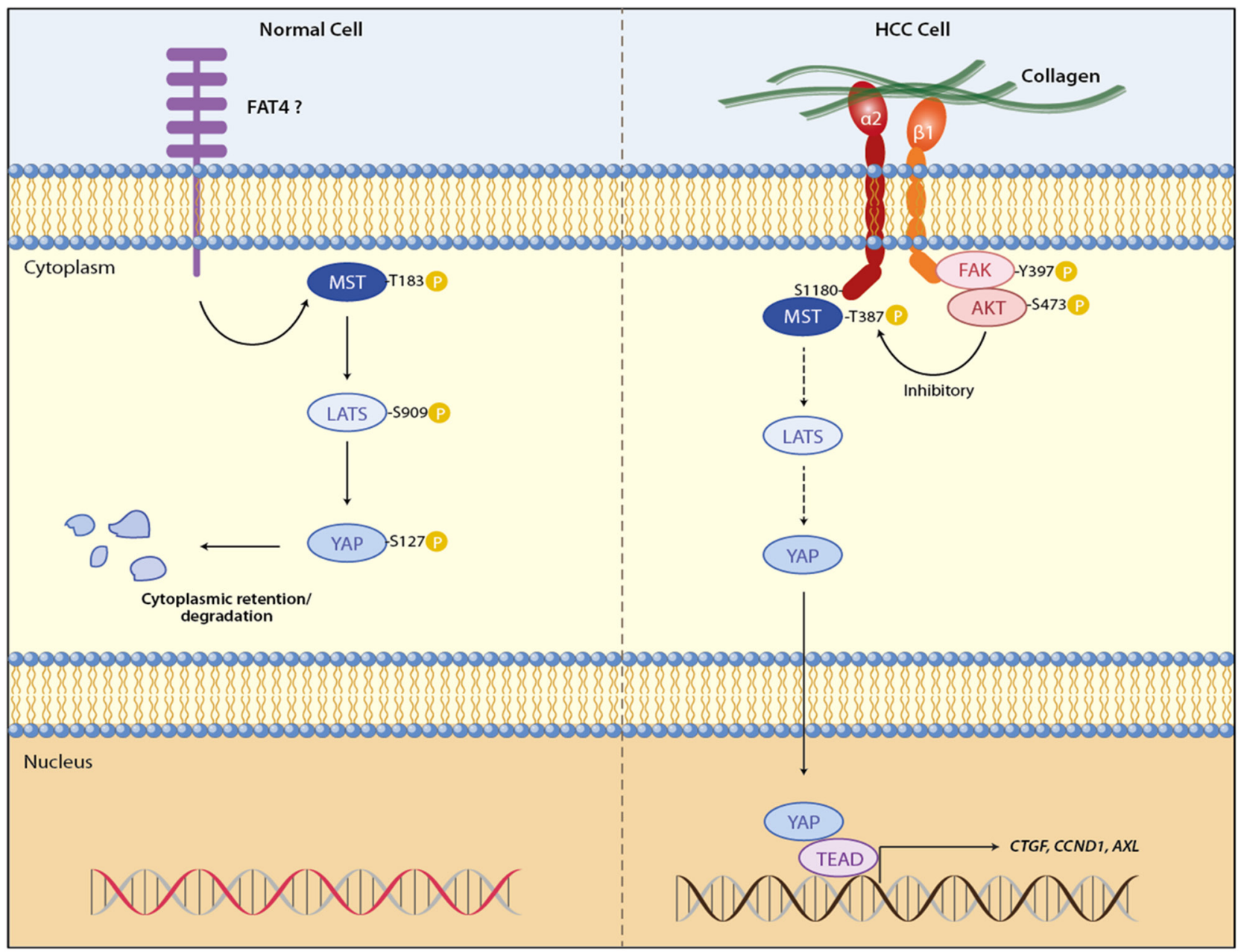

Figure 6. ECM adhesion of $\alpha 2 \beta 1$ integrin promotes YAP-mediated transcription through inhibition of MST1 of the Hippo pathway. In normal cells MST1 and LATS1 activated by extracellular signals like cell-cell contact phosphorylate YAP at S127, retaining YAP in cytoplasm for sequestration and degradation. This suppresses YAP targeted gene expression, allowing the cell to maintain homeostasis. In liver cancer cells adhesion of $\alpha 2 \beta 1$ integrin to extracellular collagen inhibits the kinase activity of MST1 and subsequently LATS1, of which the molecular mechanism involves the interaction between MST1 and S1180 of integrin $\alpha 2$. YAP is released from the negative regulation of the Hippo core kinases, and is transported into the nucleus to activate gene transcriptions for cell proliferation and survival, helping cancer cells overcome the cell-cell contact inhibition. 


\section{MATERIALS AND METHODS}

\section{Antibodies, FAK inhibitor, cell culture, and transfection}

MST1 (rabbit polyclonal, \#3682), p-T183-MST1 (rabbit polyclonal, \#3681), LATS1 (rabbit monoclonal, \#3477), p-S909-LATS1 (rabbit polyclonal, \#9157), p-S127YAP (rabbit polyclonal, \#4911), FAK (rabbit polyclonal, \#3285), p-Y397-FAK (rabbit polyclonal, \#3283), AKT (rabbit polyclonal, \#9272), and p-S473-AKT (rabbit monoclonal, \#3787) antibodies were purchased from Cell Signaling Technology (Danvers, MA). Endogenous YAP (rabbit polyclonal, \#PAB9591) antibody was purchased from Abnova (Taipei, Taiwan). Anti-serum against p-T387MST1 was from Prof. Ye of the Emory University School of Medicine (Atlanta, GA). FAK inhibitor Y15 was from Selleck Chemicals (Houston, TX). Hepatoma cell lines Huh7, Hep3B and PLC were obtained and cultured as described [55]. All siRNAs including negative controls (20 $\mu \mathrm{M})$ (Life Technologies, Carlsbad, CA) were transfected using Lipofectamine RNAiMax (Life Technologies).

\section{Integrin subunit cDNA constructs and site- directed mutagenesis}

The cDNA fragments of the cytoplasmic tails of integrin $\alpha 2$ and $\beta 1$ were cloned into pci-puro-MCS-FLAG vector through EcoRI and NotI restriction sites, allowing the pull-down of the N-terminal FLAG-tagged proteins by anti-FLAG affinity gel. Overlapping PCR was done as described to substitute S1180 and S1181 of integrin $\alpha 2$ with alanine [56].

\section{Collagen binding experiment}

Huh7 cells were seeded on culture plates coated with $0.4 \mathrm{mg} / \mathrm{mL}$ collagen IV (Sigma \& Co., St. Louis, MO) and one day later, were treated with siRNAs: control, integrin $\alpha 2$ or $\beta 1$ siRNAs; or antibodies: mouse IgG or $\alpha 2 \beta 1$ integrin function-blocking antibody BHA2.1 (mouse monoclonal, \#MAB1998Z, Millipore, Temecula, CA). After 48 hours, cell lysates were obtained for western blotting as described [57].

\section{In vitro assays}

Real-time PCR [57] and immunoprecipitation [58] were done as previously reported. To perform in vitro kinase assay, whole-cell lysate from Hep3B and PLC cells were precipitated by MST1 antibody (Cell Signaling). The washed precipitates were then used in the kinase assay. Briefly, reactions were performed in the presence of $10 \mu \mathrm{Ci}$ of $[\gamma-32 \mathrm{P}]$ ATP in $30 \mu \mathrm{l}$ assay buffer $(20 \mathrm{mM}$ HEPES, $\mathrm{pH} 7.4,10 \mathrm{mM} \mathrm{MgCl} 2$, and $1 \mathrm{mM}$ dithiothreitol) using myelin basic protein (MBP, Millipore, Temecula, CA) as the substrate. Reaction mixture was incubated at room temperature for 30 minutes, then stopped by adding SDS-PAGE sample buffer, and finally resolved by electrophoresis. After that, the incorporation of radioactive ATP into MBP was determined by autoradiography.

\section{Statistical analysis}

All values were expressed as the mean \pm S.D and statistical significance was evaluated using GraphPad PRISM for Macintosh (version 4.0; GraphPad, La Jolla, CA). The differences between all groups were evaluated by the Student's $t$ test. Expression data of integrin $\alpha 2$ and YAP targeted genes were retrieved from our previous profiling study on HBV-related HCC, of which the raw data have been deposited in GEO with accession number GSE25097 $[59,60]$. Survival analysis was performed using IBM SPSS Statistics version 19 (SPSS Inc., Chicago, IL). For Cox analysis, the regression coefficients of integrin $\alpha 2$ and YAP-targeted genes were first determined, and then be used for risk score calculation using the following formula: Risk score of each patients $=($ ITGA2 $) * 0.275+($ GPC3 $) * 0.42+$ $(S O X 4) * 0.587+(C T G F) * 0.389-(C C N D 1) * 0.05-(A X L)$ $* 0.496-(I G F 1 R) * 0.086$. Hierarchical clustering and cluster visualization was performed using Gene Cluster 3.0 and TreeView version 1.1.3, respectively.

\section{CONFLICTS OF INTEREST}

The authors declare that they have no conflicts of interest with the contents of this article.

\section{GRANT SUPPORT}

Dr. Z. Xu was supported by grants from the National Natural Science Foundation of China (No. 81370057) and the 2013 Jiangsu Government Scholarship for Visiting Scholar from Jiangshu Provincial Department of Education.

\section{REFERENCES}

1. Siegel RL, Miller KD and Jemal A. Cancer statistics, 2016. CA Cancer J Clin. 2016; 66:7-30.

2. Chen W, Zheng R, Baade PD, Zhang S, Zeng H, Bray F, Jemal A, Yu XQ and He J. Cancer statistics in China, 2015. CA Cancer J Clin. 2016; 66:115-132.

3. Sung WK, Zheng H, Li S, Chen R, Liu X, Li Y, Lee NP, Lee WH, Ariyaratne PN, Tennakoon C, Mulawadi FH, Wong KF, Liu AM, Poon RT, Fan ST, Chan KL, et al. Genomewide survey of recurrent HBV integration in hepatocellular carcinoma. Nat Genet. 2012; 44:765-769.

4. Schwartz M, Roayaie S and Konstadoulakis M. Strategies for the management of hepatocellular carcinoma. Nat Clin Pract Oncol. 2007; 4:424-432.

5. Zender L, Xue W, Zuber J, Semighini CP, Krasnitz A, Ma B, Zender P, Kubicka S, Luk JM, Schirmacher P, McCombie WR, Wigler M, Hicks J, Hannon GJ, Powers S and Lowe 
SW. An oncogenomics-based in vivo RNAi screen identifies tumor suppressors in liver cancer. Cell. 2008; 135:852-864.

6. Zender L, Spector MS, Xue W, Flemming P, Cordon-Cardo C, Silke J, Fan ST, Luk JM, Wigler M, Hannon GJ, Mu D, Lucito R, Powers S and Lowe SW. Identification and validation of oncogenes in liver cancer using an integrative oncogenomic approach. Cell. 2006; 125:1253-1267.

7. Dong J, Feldmann G, Huang J, Wu S, Zhang N, Comerford SA, Gayyed MF, Anders RA, Maitra A and Pan D. Elucidation of a universal size-control mechanism in Drosophila and mammals. Cell. 2007; 130:1120-1133.

8. Grusche FA, Degoutin JL, Richardson HE and Harvey KF. The Salvador/Warts/Hippo pathway controls regenerative tissue growth in Drosophila melanogaster. Dev Biol. 2010; 350:255-266.

9. Liu AM, Wong KF, Jiang X, Qiao Y and Luk JM. Regulators of mammalian Hippo pathway in cancer. Biochim Biophys Acta. 2012; 1826:357-364.

10. Liu CY, Zha ZY, Zhou X, Zhang H, Huang W, Zhao D, Li T, Chan SW, Lim CJ, Hong W, Zhao S, Xiong Y, Lei QY and Guan KL. The hippo tumor pathway promotes TAZ degradation by phosphorylating a phosphodegron and recruiting the SCF \{beta\}-TrCP E3 ligase. J Biol Chem. 2010; 285:37159-37169.

11. Zhao B, Li L, Tumaneng K, Wang CY and Guan KL. A coordinated phosphorylation by Lats and CK1 regulates YAP stability through SCF(beta-TRCP). Genes Dev. 2010; 24:72-85.

12. Yu FX, Zhao B and Guan KL. Hippo Pathway in Organ Size Control, Tissue Homeostasis, and Cancer. Cell. 2015; 163:811-828.

13. Liu AM, Xu Z and Luk JM. An update on targeting HippoYAP signaling in liver cancer. Expert Opin Ther Targets. 2012; 16:243-247.

14. Lamar JM, Stern P, Liu H, Schindler JW, Jiang ZG and Hynes RO. The Hippo pathway target, YAP, promotes metastasis through its TEAD-interaction domain. Proc Natl Acad Sci U S A. 2012; 109:E2441-2450.

15. Kim NG, Koh E, Chen X and Gumbiner BM. E-cadherin mediates contact inhibition of proliferation through Hippo signaling-pathway components. Proc Natl Acad Sci U S A. 2011; 108:11930-11935

16. Chen D, Sun Y, Wei Y, Zhang P, Rezaeian AH, TeruyaFeldstein J, Gupta S, Liang H, Lin HK, Hung MC and Ma L. LIFR is a breast cancer metastasis suppressor upstream of the Hippo-YAP pathway and a prognostic marker. Nat Med. 2012; 18:1511-1517.

17. Xu MZ, Yao TJ, Lee NP, Ng IO, Chan YT, Zender L, Lowe SW, Poon RT and Luk JM. Yes-associated protein is an independent prognostic marker in hepatocellular carcinoma. Cancer. 2009; 115:4576-4585.

18. Zhou Z, Hu T, Xu Z, Lin Z, Zhang Z, Feng T, Zhu L, Rong Y, Shen H, Luk JM, Zhang X and Qin N. Targeting Hippo pathway by specific interruption of YAP-TEAD interaction using cyclic YAP-like peptides. FASEB J. 2014.
19. Low BC, Pan CQ, Shivashankar GV, Bershadsky A, Sudol M and Sheetz M. YAP/TAZ as mechanosensors and mechanotransducers in regulating organ size and tumor growth. FEBS Lett. 2014.

20. Calvo F, Ege N, Grande-Garcia A, Hooper S, Jenkins RP, Chaudhry SI, Harrington K, Williamson P, Moeendarbary E, Charras G and Sahai E. Mechanotransduction and YAPdependent matrix remodelling is required for the generation and maintenance of cancer-associated fibroblasts. Nat Cell Biol. 2013; 15:637-646.

21. Aragona M, Panciera T, Manfrin A, Giulitti S, Michielin F, Elvassore N, Dupont S and Piccolo S. A mechanical checkpoint controls multicellular growth through YAP/TAZ regulation by actin-processing factors. Cell. 2013; 154:1047-1059.

22. Hao J, Zhang Y, Wang Y, Ye R, Qiu J, Zhao Z and Li J. Role of extracellular matrix and YAP/TAZ in cell fate determination. Cell Signal. 2014; 26:186-191.

23. Dupont S, Morsut L, Aragona M, Enzo E, Giulitti S, Cordenonsi M, Zanconato F, Le Digabel J, Forcato M, Bicciato S, Elvassore N and Piccolo S. Role of YAP/TAZ in mechanotransduction. Nature. 2011; 474:179-183.

24. Luk JM and Guan KL. An alternative DNA damage pathway to apoptosis in hematological cancers. Nat Med. 2014; 20:587-588.

25. Nukuda A, Sasaki C, Ishihara S, Mizutani T, Nakamura K, Ayabe T, Kawabata K and Haga H. Stiff substrates increase YAP-signaling-mediated matrix metalloproteinase-7 expression. Oncogenesis. 2015; 4:e165.

26. Madamanchi A, Santoro SA and Zutter MM. alpha2beta1 Integrin. Adv Exp Med Biol. 2014; 819:41-60.

27. Esposito $\mathrm{M}$ and Kang $\mathrm{Y}$. Targeting tumor-stromal interactions in bone metastasis. Pharmacol Ther. 2014; 141:222-233.

28. Bartolome RA, Barderas R, Torres S, Fernandez-Acenero MJ, Mendes M, Garcia-Foncillas J, Lopez-Lucendo M and Casal JI. Cadherin-17 interacts with alpha2beta1 integrin to regulate cell proliferation and adhesion in colorectal cancer cells causing liver metastasis. Oncogene. 2014; 33:1658-1669.

29. Dudley DT, Li XY, Hu CY, Kleer CG, Willis AL and Weiss SJ. A 3D matrix platform for the rapid generation of therapeutic anti-human carcinoma monoclonal antibodies. Proc Natl Acad Sci U S A. 2014; 111:14882-14887.

30. Xu MZ, Chan SW, Liu AM, Wong KF, Fan ST, Chen J, Poon RT, Zender L, Lowe SW, Hong W and Luk JM. AXL receptor kinase is a mediator of YAP-dependent oncogenic functions in hepatocellular carcinoma. Oncogene. 2011; 30:1229-1240.

31. Lu L, Li Y, Kim SM, Bossuyt W, Liu P, Qiu Q, Wang Y, Halder G, Finegold MJ, Lee J-S and Johnson RL. Hippo signaling is a potent in vivo growth and tumor suppressor pathway in the mammalian liver. Proc Natl Acad Sci USA. 2010; 107:1437-1442.

32. Chan SW, Lim CJ, Chong YF, Pobbati AV, Huang C and Hong W. Hippo pathway-independent restriction of TAZ and YAP by angiomotin. J Biol Chem. 2011; 286:7018-7026. 
33. Fink J, Carpi N, Betz T, Betard A, Chebah M, Azioune A, Bornens M, Sykes C, Fetler L, Cuvelier D and Piel M. External forces control mitotic spindle positioning. Nat Cell Biol. 2011; 13:771-778.

34. Masumoto A, Arao S and Otsuki M. Role of beta1 integrins in adhesion and invasion of hepatocellular carcinoma cells. Hepatology. 1999; 29:68-74.

35. Burnier JV, Wang N, Michel RP, Hassanain M, Li S, Lu Y, Metrakos P, Antecka E, Burnier MN, Ponton A, Gallinger $\mathrm{S}$ and Brodt $\mathrm{P}$. Type IV collagen-initiated signals provide survival and growth cues required for liver metastasis. Oncogene. 2011; 30:3766-3783.

36. Ho WC, Heinemann C, Hangan D, Uniyal S, Morris VL and Chan BM. Modulation of in vivo migratory function of alpha 2 beta 1 integrin in mouse liver. Mol Biol Cell. 1997; 8:1863-1875.

37. Hangan D, Uniyal S, Morris VL, MacDonald IC, von Ballestrem C, Chau T, Schmidt EE, Chambers AF, Groom $\mathrm{AC}$ and Chan BM. Integrin VLA-2 (alpha2beta1) function in postextravasation movement of human rhabdomyosarcoma RD cells in the liver. Cancer Res. 1996; 56:3142-3149.

38. Jaalouk DE and Lammerding J. Mechanotransduction gone awry. Nat Rev Mol Cell Biol. 2009; 10:63-73.

39. Mammoto $T$ and Ingber DE. Mechanical control of tissue and organ development. Development. 2010; 137:1407-1420.

40. Jaalouk DE and Lammerding J. Mechanotransduction gone awry. Nat Rev Mol Cell Biol. 2009; 10:63-73.

41. Vogel V and Sheetz M. Local force and geometry sensing regulate cell functions. Nat Rev Mol Cell Biol. 2006; $7: 265-275$.

42. Dupont S. Role of YAP/TAZ in cell-matrix adhesion-mediated signalling and mechanotransduction. Exp Cell Res. 2015.

43. Serrano I, McDonald PC, Lock F, Muller WJ and Dedhar S. Inactivation of the Hippo tumour suppressor pathway by integrin-linked kinase. Nat Commun. 2013; 4:2976.

44. Bartolome RA, Pelaez-Garcia A, Gomez I, Torres S, Fernandez-Acenero MJ, Escudero-Paniagua B, Imbaud JI and Casal JI. An RGD motif present in cadherin 17 induces integrin activation and tumor growth. J Biol Chem. 2014; 289:34801-34814.

45. Ihara S, Hagedorn EJ, Morrissey MA, Chi Q, Motegi F, Kramer JM and Sherwood DR. Basement membrane sliding and targeted adhesion remodels tissue boundaries during uterine-vulval attachment in Caenorhabditis elegans. Nat Cell Biol. 2011; 13:641-651.

46. Kalluri R. Basement membranes: structure, assembly and role in tumour angiogenesis. Nat Rev Cancer. 2003; 3:422-433.

47. Song H, Mak KK, Topol L, Yun K, Hu J, Garrett L, Chen Y, Park O, Chang J, Simpson RM, Wang CY, Gao B, Jiang $\mathrm{J}$ and Yang Y. Mammalian Mst1 and Mst2 kinases play essential roles in organ size control and tumor suppression. Proc Natl Acad Sci U S A. 2010; 107:1431-1436.

48. Angus L, Moleirinho S, Herron L, Sinha A, Zhang X, Niestrata M, Dholakia K, Prystowsky MB, Harvey KF, Reynolds PA and Gunn-Moore FJ. Willin/FRMD6 expression activates the Hippo signaling pathway kinases in mammals and antagonizes oncogenic YAP. Oncogene. 2011; 31:238-250.

49. Morinaka A, Funato Y, Uesugi K and Miki H. Oligomeric peroxiredoxin-I is an essential intermediate for $\mathrm{p} 53$ to activate MST1 kinase and apoptosis. Oncogene. 2011; 30:4208-4218.

50. Qiao M, Wang Y, Xu X, Lu J, Dong Y, Tao W, Stein J, Stein GS, Iglehart JD, Shi Q and Pardee AB. Mst1 is an interacting protein that mediates PHLPPs' induced apoptosis. Mol Cell. 2010; 38:512-523.

51. Ni L, Li S, Yu J, Min J, Brautigam CA, Tomchick DR, Pan D and Luo X. Structural basis for autoactivation of human Mst2 kinase and its regulation by RASSF5. Structure. 2013; 21:1757-1768.

52. Metcalf DG, Moore DT, Wu Y, Kielec JM, Molnar K, Valentine KG, Wand AJ, Bennett JS and DeGrado WF. NMR analysis of the alphaIIb beta3 cytoplasmic interaction suggests a mechanism for integrin regulation. Proc Natl Acad Sci U S A. 2010; 107:22481-22486.

53. Wang Z, Leisner TM and Parise LV. Platelet alpha2betal integrin activation: contribution of ligand internalization and the alpha2-cytoplasmic domain. Blood. 2003; 102:1307-1315.

54. Klekotka PA, Santoro SA, Wang H and Zutter MM. Specific residues within the alpha 2 integrin subunit cytoplasmic domain regulate migration and cell cycle progression via distinct MAPK pathways. J Biol Chem. 2001; 276:32353-32361.

55. Liu LX, Lee NP, Chan VW, Xue W, Zender L, Zhang C, Mao M, Dai H, Wang XL, Xu MZ, Lee TK, Ng IO, Chen Y, Kung HF, Lowe SW, Poon RT, et al. Targeting cadherin-17 inactivates Wnt signaling and inhibits tumor growth in liver carcinoma. Hepatology. 2009; 50:1453-1463.

56. Wong KF, Luk JM, Cheng RH, Klickstein LB and Fan ST. Characterization of two novel LPS-binding sites in leukocyte integrin betaA domain. FASEB J. 2007; 21:3231-3239.

57. Liu AM, Poon RT and Luk JM. MicroRNA-375 targets Hippo-signaling effector YAP in liver cancer and inhibits tumor properties. Biochem Biophys Res Commun. 2010; 394:623-627.

58. Zhu R, Wong KF, Lee NP, Lee KF and Luk JM. HNF1alpha and CDX2 transcriptional factors bind to cadherin-17 (CDH17) gene promoter and modulate its expression in hepatocellular carcinoma. J Cell Biochem. 2010; 111:618-628.

59. Ivanovska I, Zhang C, Liu AM, Wong KF, Lee NP, Lewis P, Philippar U, Bansal D, Buser C, Scott M, Mao M, Poon RT, Fan ST, Cleary MA, Luk JM and Dai H. Gene signatures derived from a c-MET-driven liver cancer mouse model predict survival of patients with hepatocellular carcinoma. PLoS One. 2011; 6:e24582.

60. Lamb JR, Zhang C, Xie T, Wang K, Zhang B, Hao K, Chudin E, Fraser HB, Millstein J, Ferguson M, Suver C, Ivanovska I, Scott M, Philippar U, Bansal D, Zhang Z, et al. Predictive genes in adjacent normal tissue are preferentially altered by $\mathrm{sCNV}$ during tumorigenesis in liver cancer and may rate limiting. PLoS One. 2011; 6:e20090. 